Ročník XVII (2015), číslo 1, s. 120-125/ Volume XVII (2015), Issue 1, pp. 120-125

(c) Mezinárodní politologický ústav / International Institute of Political Science

DOI: $10.5817 / C E P S R .2015 .1 .120$

\title{
Milan Znoj, Jan Bíba, Jana Vargovčíková: Demokracie v postliberální konstelaci
}

Praha: Karolinum, 2014. 240 s., ISBN 978-80-246-2878-3

MARIÁN SEKERÁK ${ }^{1}$

Téma demokracie je stále atraktívna. Prinajmenšom na poli politickej vedy a príbuzných disciplín. Presne toto by sme mohli konštatovat' na základe čo i len letmého pohladu na vzostupný trend množstva súčasnej vedeckej spisby venovanej práve problematike liberálnej demokracie. Ceský a slovenský geografický priestor v tomto nie je nijakou výnimkou. Dokumentuje to viacero odborných knižných publikácií a kapitol, ktoré vznikli v priebehu posledných piatich rokov práve so zameraním na rôzne aspekty a problémy demokracie (napr. Buraj et al. 2010; Plichtová 2010; Čmejrek, Bubeníček, Čopík 2010; Dobiaš, Eštok, Onufrák, Bzdilová 2012; Kučera 2012; Vančura 2012; Mareš, Výborný 2013; Sekerák 2013; Holzer et al. 2013; Kováčik 2010, 2013; Vencálek 2014; Korpášová 2014; Kulašik, Tichá 2014). Jedným z najnovších príspevkov na túto tému je prehladová vedecká monografia (odborní recenzenti: Josef Velek, Martin Šimsa) z edície POLITEIA pražského vydavatel'stva Karolinum, na ktorej sa autorsky podielal tím odborníkov z Filozofickej fakulty Univerzity Karlovej v Prahe. Ten pozostával z Milana Znoja, Jana Bíbu a Jany Vargovč́kovej. Dvaja autori a jedna autorka sa podujali na nel'ahkú úlohu: zmapovat' aktuálny diskurz o alternatívnych demokratických koncepciách vzt’ahujúcich svoju kritiku (vo väčšej alebo menšej miere) voči liberálnej demokracii. Vychádzali pritom z presvedčenia, že „liberálna demokracia je v úzkych a známky tejto neuspokojivej situácie vidíme nielen v praktickej politike, ale nachádzame ich taktiež v samotných liberálnodemokratických teoretických konceptoch“ (s. 11). Tento moment pomenovali súhrnným názvom „postliberálna demokracia“, čím chceli čo najpresnejšie vystihnút' jej aktuálny stav. Hned’ na úvod však zároveň možno poznamenat', že ponúknutý náčrt liberálnej demokracie je do istej miery schematický a nie vždy

\footnotetext{
1 Interný doktorand v odbore politológia na Institutu politologických studií, Fakulta sociálních věd, Univerzita Karlova. U Krríže 8, 158 00, Praha 5 - Jinonice, Česká republika / Czech Republic. E-mail: marian.sekerak@gmail.com. Recenzia vychádza v rámci inštitucionálnej podpory IPS FSV UK v Prahe. Za cenné pripomienky k pôvodnej verzii tohto textu d'akujem Pavlovi Dufekovi.
} 
berie $\mathrm{v}$ plnej miere do úvahy diskusie $\mathrm{v}$ rámci celej šírky liberálnej teórie demokracie.

V piatich kapitolách nájdeme prehl’adne usporiadaný súbor starších i novších demokratických a liberálnych koncepcií, prakticky od čias J. Locka a I. Kanta až po autorov a autorky 20. a 21. storočia, akými boli či sú C. B. Macpherson alebo Ch. Mouffe. Výber konkrétnych analyzovaných konceptov môže do určitej miery pôsobit' trochu eklekticky, a to podl’a zásady: čo vlastný vedecký záujem autora (autorky), to kapitola. $\mathrm{Na}$ druhej strane, jednotlivým častiam nemožno upriet' fundovanost' a jasnost' výkladu. Kniha ako celok pôsobí koherentne, jednotlivé kapitoly na seba odkazujú a vol'ne nadväzujú. Sympatické je, že autorská trojica vo svojich kapitolách nerezignovala na kritiku a zhodnotenie jednotlivých konceptov, ale ponúkla aj vlastné podnetné i zaujímavé pohl’ady na ne. Pre knihu je teda charakteristická nielen syntetizácia a kompilácia cudzích poznatkov a teoretických pohladov na liberalizmus a demokraciu, ale aj ich analýza a kritické zhodnocovanie. $\mathrm{Na}$ základe toho sa $\mathrm{v}$ diele snúbi dôkladný didaktický prístup učebnice s analytickou metódou vedeckých monografií, ktorá zároveň kladie na čitatel'ov pomerne vysoké percepčné nároky.

V prvej kapitole z pera M. Znoja sa oboznamujeme s prehl'adom politickej teórie liberalizmu u Johna Locka a Immanuela Kanta, pričom vzápätí prechádzame ku kompetitívnej (procedurálnej) demokracii J. A. Schumpetera a reprezentantom teórie racionálnej (spoločenskej) vol'by. Vzhl’adom na d’alšie časti knihy mala táto pomerne krátka kapitola zrejme pôsobit' ako „úvod do problematiky“, avšak táto úloha bola plne zvládnutá už v úvode, kvôli čomu môže čitatel'ovi/čitatel'ke uniknút' skutočný zmysel 1. kapitoly. Tento pocit umocňuje už aj (náhodný?) výber predkladaných teoretických koncepcii a ich vzájomná komparácia. Druhá kapitola - autorom ktorej je opät' M. Znoj - už ponúka rozsiahlejší pohl'ad na demokraciu z pozície republikanizmu, ktorý tvrdí, že „demokracia sa nezaobíde bez záujmu občanov o veci verejné, bez ich ochoty bránit' spoločnú slobodu a ich schopnosti formulovat' vlastné záujmy, posúdit' záujmy druhých (...)“ (s. 73). Základnými orientačnými bodmi a zároveň východiskami sú v tejto kapitole predovšetkým prístupy J.-J. Rousseaua a G. W. F. Hegela, ktorých renomovaným znalcom Milan Znoj nepochybne je. Následne je dôkladná pozornost' venovaná niektorým črtám politického myslenia H. Arendtovej, aby v závere kapitoly prišli „,k slovu“ aj teoretici súčasného republikanizmu (P. Pettit, Ch. List), ktorí znovu premýšlajú princípy inštitucionálneho sprostredkovania kolektívnych záujmov spoločnosti v rámci princípu demokratickej reprezentácie, a ktoré reagujú na negáciu a spochybňovanie idey spoločného dobra, s ktorou sa stretávame predovšetkým v prístupe teórie racionálnej vol’by.

Tretia kapitola napísaná J. Vargovčíkovou predstavuje dôkladný prehlad doteraz v českom prostredí stále málo známej teórie deliberatívnej demokracie, ktorá sa $\mathrm{v}$ priebehu viac než dvoch desat'ročí (najmä $\mathrm{v}$ angloamerickej politickej 
vede a filozofii) značne rozrástla a rozčlenila na viacero vnútorných prúdov. Autorka v nej nepribližuje iba základné princípy a znaky deliberatívnej demokracie, ktorej zmyslom je „znovuobjavit' dialogický charakter demokratického rozhodovania“ (s. 95), ale reflektuje aj dlhodobé a stále aktuálne otázky, ktoré v súvislosti s ňou vyvstávajú, akým je napríklad problematika reflexie partikulárnych záujmov účastníkov deliberácie, fenomén stretu individuálnych identít, sociálneho determinizmu a diskurzívneho ukotvenia deliberatívnych praxí, ale aj stále sa navracajúcu otázku možností efektívnej verejnej deliberácie v podmienkach vel'kých (čo do rozlohy i počtu obyvatel’ov) liberálnodemokratických štátov.

Štvrtá a piata kapitola, autorom ktorých je J. Bíba, ponúkajú kvalitný náhl’ad na súdobé teoretické prístupy $\mathrm{k}$ demokracii $\mathrm{z}$ pohl'adu kanadského politického teoretika C. B. Macphersona, talianskeho politológa Norberta Bobbia (oboch radených viac alebo menej do tábora liberálnych socialistov), francúzskeho filozofa Clauda Leforta, argentínskeho postmarxistického teoretika Ernesta Laclaua ( $\mathrm{k}$ jeho dielu a filozofickému odkazu pozri napr. Bíba 2014) a jeho manželky, belgickej teoretičky Chantal Mouffeovej (stručný prehl’ad myslenia Laclaua a Mouffeovej o radikálnej demokracii ponúkajú aj Barša a Císař 2004: 4262). Hodnotnou je nielen prepracovaná komparácia ich myslenia, ale aj vierohodná kritika a polemika, ktorú Bíba vo svojich riadkoch ponúka. Opomenuté však napriek tomu ostávajú niektoré črty analyzovaných koncepcií, ktoré by zvládli konfrontáciu s inými prístupmi, napríklad s tým, ktorý ponúka $\mathrm{K}$. Marx. Ako inak by bolo možné interpretovat', povedzme, Macphersonov koncept extraktívnej moci (extractive power), ktorej kvintesenciou je „získavanie prospechu z druhých“ (s. 151), než ako Marxovu ideu vykorist'ovania v rámci širšieho sociálneho pola? Ťažko uverit', že by takéto očividné podobnosti oboch teórií ostali v 4. kapitole opomenuté čírou náhodou. $\mathrm{Na}$ druhej strane, je potrebné uznat', že J. Bíba v iných častiach textu rozhodne neprehliada marxistickú inšpiráciu Macphersonovho diela, ktorému následne vyčíta napr. prílišný optimizmus ohl'adom možnosti technológii vylepšovat' l'udské životy alebo forsírovanie apolitickej vízie spoločenského života „oslobodeného“ od konfliktu a názorového pluralizmu (porov. s. 175-177; k jeho mysleniu pozri tiež Barša, Císař 2004: 63-69). Aj v týchto spomínaných častiach knihy sa napokon ako bumerang vracia výzva, ktorú demokracii nastolilo jej schumpeterovské vnímanie, odmietajúce ideu spoločného (všeobecného) dobra. Ako odpoved' preto prichádza myšlienka radikálnej demokracie, vo svojej podstate značne heterogénna a mnohoznačná, ktorá reaguje na problém plurality podôb zápasov a konfliktov v demokracii či demokratického perfekcionizmu (porov. s. 218).

Pri zmienke o koncepte radikálne demokratickej politiky v rámci 5. kapitoly je trochu prekvapujúce, že tam nenájdeme aspoň pár viet o projektoch Benjamina Barbera (2003 [1984]); dve zmienky o ňom sú len okrajové, k nemu pozri z českej literatúry napr. Barša, Císař 2004: 63-66) či Joshuu Cohena a Archona Funga 
(2004; pozri tiež Warren 1996). Nepochybne zaujímavou by mohla byt' aj polemika (alebo súhlas?) so starším názorom súčasného politického teoretika Marka E. Warrena (1996: 241), podl’a ktorého je už zmienená deliberatívna demokracia len jednou z verzií demokracie radikálnej. Táto výhrada je však čisto subjektívna, ked'že, samozrejme, nemožno očakávat' od autorov, že sa „popasujúc s každým normatívnym výrokom, ktorý bol v súvislosti s aktuálnym vývojom teórií demokracie vodbornej komunite vyslovený. Navyše je potrebné pripomenút', že autor 5. kapitoly zdôrazňuje, že výhodou radikálnej demokracie je práve jej antiesencialistický prístup (pozri s. 204), na ktorý sa sústredí, čo môže významne vysvetl'ovat' toto opomenutie. Informovanejšieho čitatel'a však môže nepochybne zaskočit', že v 4. kapitole o postliberálnej demokracii, ktorá bola definovaná ako „pokus o dosiahnutie socializmu prostredníctvom reformulácie nie popretia - liberálno-demokratických princípov“ (s. 203), neobjavíme žiadny odkaz na dodnes vel'mi diskutovanú Rawlsovu koncepciu tzv. liberálneho socializmu, resp. demokracie založenej na vlastníctve (Rawls 2001; pozri tiež Sekerák 2014), hoci je ona sama niekedy vnímaná ako značne vágna a de facto neodpovedajúca (alebo len slabo odpovedajúca) na problémy, na ktoré autori v knihe upozorňujú. Je tiež škoda, že väčšia pozornost' nebola venovaná samostatnej teórii participačnej demokracie, ktorá je výraznou a dôležitou súčast'ou najmä teórie C. B. Macphersona (pozri s. 161-163) a v súčasnosti sa spolu s deliberáciou môže javit' ako jedna z možných riešení krízy zastupitel'skej demokracie, a to najmä v súvislosti so vzrastajúcou tendenciou zapájania občanov do správy verejných záležitostí, napr. v podobe participatívneho rozpočtovania či početných protestných hnutí a skupín s globálnym dosahom a rozsahom.

Malá výhrada voči recenzovanej monografii $z$ formálnej stránky tiež môže smerovat' k spôsobu používania niektorých termínov, ktoré pochádzajú z anglického jazyka a doposial' nemajú ustálený ekvivalent v češtine. Ide napríklad o slová „publicita“ (s. 104, 105) v zmysle „verejnost““ či „presupozice“ (s. 119). V prvom prípade autorka textu 3. kapitoly má zjavne na mysli verejný charakter deliberácie, teda aktívnu prítomnost' zainteresovaných osôb (občanov) na deliberácii. Toto slovo však má aj iné významové odtienky, a preto by azda bolo vhodné pouvažovat' nad iným výrazom, resp. nad rozvedeným vyjadrením tohto pojmu v podobe viacerých slov. Druhý termín je prevzatý z lingvistiky, kde označuje implicitnú domnienku o svete/spoločnosti alebo nevyjadrený (skrytý) predpoklad či vieru týkajúcu sa výpovede, ktorá sa v rámci diskurzu považuje za danú, prípustnú. V samotnom texte však tento termín vysvetlený nebol a pracuje sa s ním ako so všeobecne známym, čo pre menej informovaných čitatelov nemusí byt' príliš pohodlné. Preto by mohlo byt' vhodné umiestnenie adekvátneho vysvetlenia tohto slova napr. do poznámky pod čiarou, alebo rovno použitie iného, vhodnejšieho termínu zaužívaného v českom jazyku. V tomto prípade by sa zrejme najviac pôvodnému významu slova približovalo podstatné meno „domnienka“ ( $\mathrm{v}$ češtine domněnka). 
Napriek uvedeným menším pripomienkam a relatívne širokému „rozkročeniu“ záberu publikácie, ktoré sa týka vel’kého časového rozsahu preberaných konceptov (od Platóna v 1. kapitole až po Nadiu Urbinati, súčasnú politologičku pôsobiacu na Kolumbijskej univerzite v New Yorku), možno kolektívnu monografiu „Demokracie v postliberálni konstelaci“ označit' prinajmenšom ako vel'mi vydarený pokus ponúknut' čitatel'skej verejnosti českého (a autor tejto recenzie nepochybuje o tom, že aj slovenského) geografického priestoru prehl’adný súbor názorov a polemík o súčasnom stave liberálnej demokracie. Recenzovaná kniha poskytuje zároveň množstvo originálnych podnetov, ktoré kriticky rozvíjajú predložené koncepty. Možno preto vyjadrit' presvedčenie, že sa stane jednou z tých publikácí́, po ktorej budú (povinne?) siahat' nielen študenti a študentky politológie a príbuzných disciplín, ale aj zainteresovaní odborníci a odborníčky, ktorí/é v nej nepochybne nájdu inšpiráciu pre svoj d’alší základný a/alebo aplikovaný výskum.

\section{Bibliografie}

Barber, Benjamin R. (2003) [1984]: Strong democracy: participatory politics for a new age. 20th anniversary edition with a new preface. Berkeley: University of California Press.

Barša, Pavel a Ondřej Císař (2004): Levice v postrevolučni době. Brno: Centrum pro studium demokracie a kultury.

Bíba, Jan (2014): „Zemřel Ernesto Laclau.“ Sociologický časopis/Cz̨ech Sociological Review 50(2): 288-289.

Buraj, Ivan a kol. (2010): Antická demokracia a sloboda a súčasnost’. Bratislava: Univerzita Komenského.

Cohen, Joshua a Archon Fung (2004): „Radical Democracy.“ Swiss Political Science Review 10(4): 23-34.

Čmejrek, Jaroslav, Václav Bubeníček a Jan Čopík (2010): Demokracie v lokálním politickém prostoru. Specifika politického života v obcich ČR. Praha: Grada.

Dobiaš, Daniel, Gabriel Eštok, Alexander Onufrák a Renáta Bzdilová (eds.) (2012): Sloboda - rovnost' - poriadok: Kam kráčaśs demokracia? Acta Facultatis philosophicae Universitatis Šafarikianae 25. Politologický zborník 1. Košice: Univerzita Pavla Jozefa Šafárika v Košiciach.

Holzer, Jan, Pavel Molek, Jiří Baroš, Pavel Dufek, Michal Mocht’ak, Ivo Pospíšil, Petr Preclík a Hubert Smekal (2013): Demokratizace a lidská práva: Stredoevropské pobledy. Brno, Praha: Muni Press, Slon.

Korpášová, Lenka (2014): „Vzostup individualizmu a nová podoba demokracie.“ In: László Öllös, David Hampl a kol.: Deset let v Evropské unii: Stav, zkeušenosti, perspektivy. Kolín: Nezávislé centrum pro studium politiky, ARC - VŠPSV, 57-69.

Kováčik, Branislav (2010): „Kríza legitimity demokratického štátu.“ In: Milan Márton (eds.), Aktuálne otázky svetovej ekonomiky a politiky. Zborník príspevkov z 10. medzinárodnej vedeckej konferencie Medzinárodné vzt’ahy 2009. Bratislava: Ekonóm, 354-363. 
Kováčik, Branislav (2013): „Elitistická demokracia: vít’azstvo realizmu?“ In: Jiř́ Bîlý, Štěpán Kavan, Roman Svatoš a kol.: Verégná správa a bezppečnost státu jako soucást udrỹitelného rožvoje. České Budějovice: Vysoká škola evropských a regionálních studií, 35-39.

Kučera, Rudolf (2012): Politologická historie demokracie: O piovodu a vývoji systému demokracie, republiky, oligarchie, tyranie, principátu, signorie a vaniku principu demokratické reprezentace a listiny práv a svobod občanu. Ústí nad Labem: Filozofická fakulta Univerzity J. E. Purkyně v Ústí nad Labem.

Kulašik, Peter a Karolina Tichá (eds.) (2014): Bariéry a paradoxy demokracie. České Budějovice: Vysoká škola evropských a regionálních studií.

Mareš, Miroslav a Štěpán Výborný (2013): Militantni demokracie ve střední Evropě. Brno: Centrum pro studium demokracie a kultury.

Plichtová, Jana (ed.) (2010): Obcrianstvo, participácia a deliberácia na Slovensku: teória a realita. Bratislava: VEDA.

Rawls, John (2001): Justice as Fairness: A Restatement. Cambridge, Mass.: Belknap Press.

Sekerák, Marián (2013): Ekonomická demokracia: Dejiny, teória a prax. Banská Bystrica: Fakulta politických vied a medzinárodných vzt’ahov Univerzity Mateja Bela v Banskej Bystrici.

Sekerák, Marián (2014): „Rawlsův model „demokracie založené na vlastnictvi““ jako alternativa k sociálnímu státu?" Politologická revue 19(2): 113-139.

Vančura, Pavel (2012): Teorie demokracie. Svitavy: Trinitas.

Vencálek, Jaroslav (2014): Teória fraktálnej demokracie. Prešov: Filozofická fakulta Prešovskej univerzity v Prešove.

Warren, Mark E. (1996): „What Should We Expect from More Democracy?: Radically Democratic Responses to Politics.“ Political Theory 24(2): 241-270. 